\title{
奇 書
}

\section{アルゴンイオン衝撃によるニッケルの \\ 仕事関数変化と昇温脱離}

\author{
羽 含 倫 敬* ・梅 村 耕 造* \\ (昭和 48 年 5 月 5 日受理)
}

\section{1. 緒言}

金属表面を清浄化するため金属を Ar イオンで衝揧す ると，表面原子のスパッタリングが抢こるとともに金属 内部に $\mathrm{Ar}$ 原子が埋为込まれる。 $\mathrm{Ar}$ イオン衝撃により $\mathrm{Ni}$ 内部に捕捉されている $\mathrm{Ar}$ の状態を明らかにするため に, 多結晶 $\mathrm{Ni}$ 表面を $\mathrm{Ar}$ イオンのエネルギーを変えて衝 撃し仕事関数の変化の測定と昇温.脱離実験定行なった。 その結果, $\mathrm{Ni}$ の $\mathrm{Ar}$ 捕捉に関して，二，三の興味ある結 果を得たので報告する.

\section{2. 実験装置および方法}

測定セルを Fig. 1 亿示した。 Wフィラメント $(0.06$ $\mathrm{mm} \phi)$ とU字型に張った試料の $\mathrm{Ni}$ リボン $(60 \mathrm{~mm} \times 0.35$ $\mathrm{mm} \times 0.014 \mathrm{~mm})$ をセル中央部で垂直に交差させた。 セ ル内壁は $\mathrm{SnO}_{2}$ でコーティングし, 任意の電位を与える ことができるようにした，セル下部のBA ゲージは，Ar イオン衝撃のときイオン源として使用し, また昇温脱離 実験に㧍いては圧力測定に用いた。

多結晶 Ni リボンは電解研磨・リンス後, 測定セルに 取付けた。 セルを排気し, 圧力が $7 \times 10^{-6}$ Torr で一定

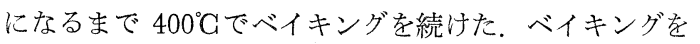
止めた後, BA ゲージの電極の電子衝撃とフラッシング による脱ガスを繰返すことによって測定セル内部の圧力 は $4 \times 10^{-9}$ Torr で一定になった。

つぎに液体窒素トラップを通して不純物を除去した Ar をセルに導入し，Ar 圧を 10 $0^{-4}$ Torr に保って排気し ながら，イオンエネルギー $500 \mathrm{eV}$ ，イオン流密度 $40 \mu \mathrm{A} /$ $\mathrm{cm}^{2}$ で 5 分間 $\mathrm{Ni}$ 表面をイオン衝撃した。つぎに $\mathrm{Ar} の$ 導入を止めてセル内の圧力が $2 \sim 3 \times 10^{-8}$ Torr に達した 後, $\mathrm{Ni}$ を通電により約 $500^{\circ} \mathrm{C}$ に加熱してアニールした. この Ar イオン衝撃，アニーリングを数回繰返して清浄 化した $\mathrm{Ni}$ 表面を $\mathrm{Ar}$ の捕捉状態の測定に用いた。

$\mathrm{Ar}$ イオンンネルギーによる捕捉された $\mathrm{Ar}$ の状態の変

* 大阪府立大学教養部化学教室 (堺市百舎鳥梅町四丁)

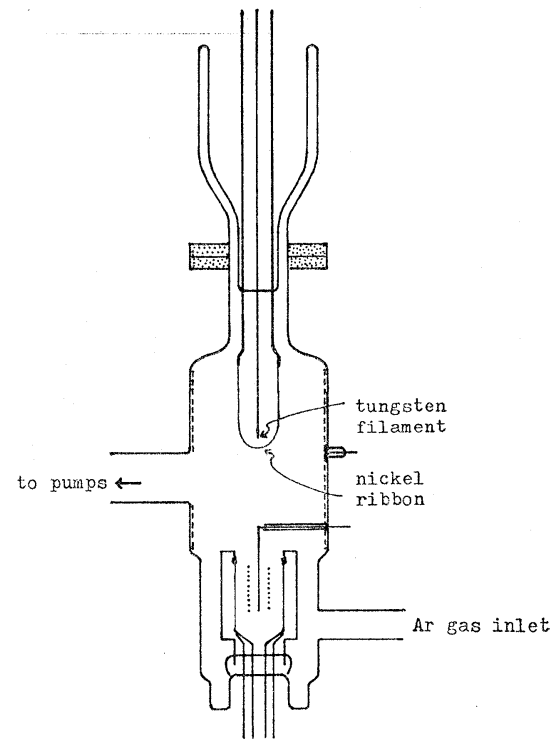

Fig. 1 Cell.

化を知るために，下記の操作を各イオンエネルギーによ るイオン衝撃每に繰返した. まず所定のエネルギーで $\mathrm{Ni}$ リボンをイオン衝撃した後，Ar が捕捉されている状態 で $\mathrm{Ni}$ の仕事関数の変化を測定し，つぎに $\mathrm{Ni}$ リボンを $500^{\circ} \mathrm{C}$ に加熱して $\mathrm{Ar}$ を脱離させた後, 室温に戻して仕 事関数の変化を測定した。 また加熱時の瞬間的な圧力上 昇から脱離した $\mathrm{Ar}$ 原子数を計算した。

仕事関数の変化の測定は, Wフィラメントを電子源と し Ni リボンを陽極とする二極管法で行なった。

昇温制御回路は Fig. 2 亿示した。 Redhead の分析 計 ${ }^{1)}$ と同様に, $\mathrm{Ni}$ リボンの温度を示す電圧 $\mathrm{E}_{\mathbf{0}}$ と基準電 圧 $\mathrm{Er}$ とを比較し，その差に応じて加熱電流を流すこと により，Ni リボンの温度は制御できる.Fig. 2 の VRに より基準電圧 Er を時間に対して linear に変えることに よって, Ni リボンの温度を室温からキュリー温度 $358^{\circ} \mathrm{C}$ までの範囲でほぼ linear に増加させることができた。 


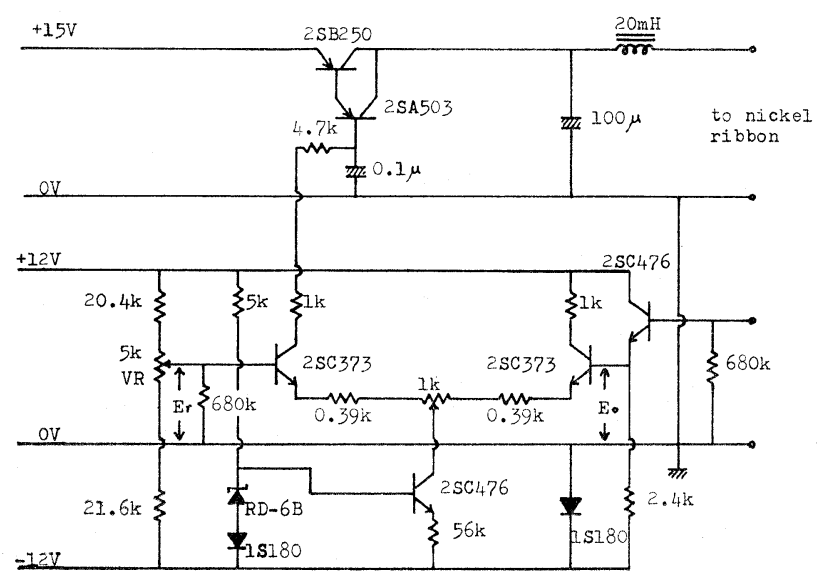

Fig. 2 Sample heating controller circuit.

\section{3. 実験結果および考察}

Ar イオンエネルギーの違いによる Ni の仕事関数の変 化を Fig. 3 に示した。同図沈いて，イオンエネルギ 一を 100, 500, $900 \mathrm{eV}$ と変えてイオン流密度 $10 \mu \mathrm{A} / \mathrm{cm}^{2}$ で 3 分間イオン衝撃したときの仕事関数変化を○で示 し，この表面を $500^{\circ} \mathrm{C}$ に加熱し室温に戻したときの仕事 関数変化をで示した。 これらの值は, 二極管特性曲線 の空間電荷制限領域に捜ける水平方向のシフトから求め たものであり, 測定精度は $\pm 0.01 \mathrm{~V}$ である. Ni の仕事 関数の測定は, Wフィラメントの仕事関数を一定に保っ て行なう必要があるため, Ar イオン衝撃はWフィラメ ントに対して行なわず，また $\mathrm{Ni}$ の仕事関数の変化を測 定ナる都度あらかじめWフィラメントをフラッシュし た. Fig. 3 より,イオン流密度 $10 \mu \mathrm{A} / \mathrm{cm}^{2}$ で 3 分間のAr イオン衝撃により仕事関数の変化は $-0.17 \sim+0.13 \mathrm{eV}$ と比較的小さい值を示し，イオンエネルギーの増加とと もに Ni の仕事関数は増加の方向を示すこと, Ni リボン の加熱によりその絶対值は隇少すること, 杍よび脱離 $\mathrm{Ar}$ 原子数は $6.0 \sim 7.2 \times 10^{15} \mathrm{atoms} / \mathrm{cm}^{2}$ であることが知られ た. Farnsworth $ら^{233)}$ は, $\mathrm{Ag}, \mathrm{Au}$ の蒸着膜の仕事関数 はアニーリングによって僅かに増加するという結果を示 し，さらにイオンエネルギー200 $600 \mathrm{eV}$ ，イオン流密 度 $100 \mu \mathrm{A} / \mathrm{cm}^{2}$ で $\mathrm{Ar}$ イオン衝撃した (100) $\mathrm{Ni}$ 表面をア ニールすると仕事関数は $0.04 \sim 0.14 \mathrm{eV}$ 増加するという 結果を得た。これらの結果との比較により，本実験にお いて $100 \mathrm{eV}$ および $500 \mathrm{eV}$ でのイオン衝撃により仕事 関数が減少した原因は，衝撃イオンのスパッタリングに より $\mathrm{Ni}$ 表面が粗くなり表面の電子の“smoothing effect” 4)が小さくなったためと考えられる。しかし，イオンエ ネルギーが増加するとともに仕事関数の変化は負の值か ら正の值になった。この原因は “smoothing effect” では

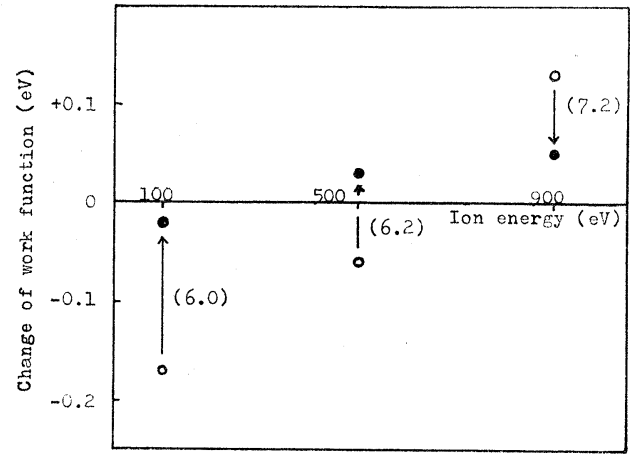

Fig. 3 Change of work function versus bombarding argon ion energy.

$\bigcirc$ : bombarded with argon ions of $10 \mu \mathrm{A} / \mathrm{cm}^{2}$ for $3 \mathrm{~min}$

- heat-treated at $500^{\circ} \mathrm{C}$

Values in parentheses show number of argon atoms desorbed $\left(\times 10^{-15}\right.$ atoms $\left./ \mathrm{cm}^{2}\right)$.

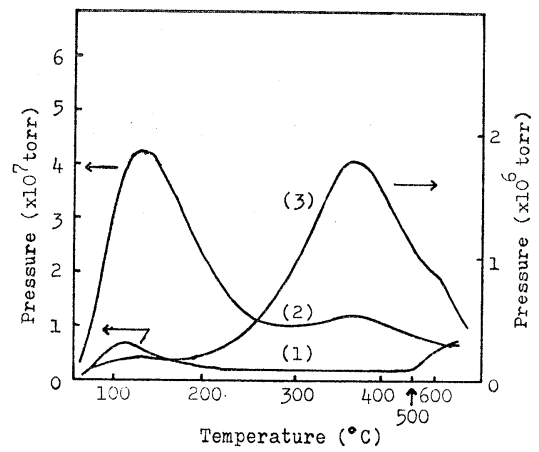

Fig. 4 Thermal desorption spectra.

(1): cleaned by argon ion bombardment and annealing

(2) : bombarded with $100 \mathrm{eV}$ argon ions of 10 $\mu \mathrm{A} / \mathrm{cm}^{2}$ for $3 \mathrm{~min}$

(3): bombarded with $500 \mathrm{eV}$ argon ions of 40 $\mu \mathrm{A} / \mathrm{cm}^{2}$ for $5 \mathrm{~min}$ 
説明できないため，これ以外の現参，例えば Ar 原子の $\mathrm{Ni}$ 内部への捕捉等によるものと推定される.

つぎに異なった条件下で $\mathrm{Ar}$ イオン衝撃した Niで得た 昇温脱離曲線を Fig. 4 に示した (昇温速度約 $3^{\circ} \mathrm{C} / \mathrm{sec}$ ). 曲線(2)は $100 \mathrm{eV}, 10 \mu \mathrm{A} / \mathrm{cm}^{2}$ で 3 分間のイオン衝撃によ って得たものであり，曲線(3)は $500 \mathrm{eV}, 40 \mu \mathrm{A} / \mathrm{cm}^{2}$ で 5 分間のイオン衝撃で得たものである.イオン衝撃・アニ ーリングによって清浄化したニッケル表面で得た昇温脱 離曲線(1)との比較により, 曲線(2), (3)の圧力変化梳留 気体または $\mathrm{Ar}$ 気体中の不純物の吸着によるものでない ことを確かめた，Fig。 4 から Ar の脱離速度が最大にな る温菖を求め, 曲線(2)では $110^{\circ} \mathrm{C}$, 曲線(3)では $340^{\circ} \mathrm{CK}$

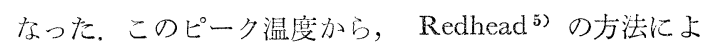
り Ar の脱離の活性化エネルギーを計算し，それぞれ 23 $\mathrm{kcal} / \mathrm{mol}$ および $40 \mathrm{kcal} / \mathrm{mol}$ と得られた。界温の過程で リード線への熱の逃散があこり， Ni リボンの温度は不 均一になるため，この值は一応の目安を与えるものであ る.しかしこれより，イオン衝撃の条件が変ると異なっ た捕捉席に Ar のはトラップされることが示された，多 結晶 $\mathrm{Ni}$ リボンからの $\mathrm{Ar}$ 脱離速度曲線に㧍いて，ピーク 温度は 4 力所 ${ }^{6)}$ また 6 力所 ${ }^{7)}$ にあるとが示されてい るため, 本実験に执てもさらに Ar イオン衝撃の条件 を変えることにより，新たなピークが現われると推定さ れる。

\section{4. 結 語}

イオンエネルギー $100 \mathrm{eV}$, イオン流密度 $10 \mu \mathrm{A} / \mathrm{cm}^{2}$ で 3 分間 Ar イオン衝撃した多結晶 Ni の仕事関数は 0.17
$\mathrm{eV}$ 減少し，イオン流密度と衝撃時間を変えずにイオン エネルギーのみを增加させたときの仕事関数は増加し $900 \mathrm{eV}$ でのイオン衝撃によって $0.13 \mathrm{eV}$ 増加した。 イ オンエネルギーの増加に伴うこの仕事関数の変化の方向 は, Ni 表面の欠宿構造の生成以外の現象によるものと 推定した.

また昇温脱離実験から，多結晶 $\mathrm{Ni} に$ 少なくとも2 種 の Ar 捕捉席があり，衝撃条件を変えると異なった捕捉 塺に Ar はトラップされることが示された。

今後さらに条件を変えて Arイオン衝撃した Ni表面に 招いて, 仕事関数の変化の測定と昇温脱離実験孛対応さ せて行なうことにより，Niに捕捉された Arの状態を究 明する予定である。

最後に, 京都大学理学部恩地勝先生に御助言戴いたこ とを感謝します。

\section{文献}

1) P. A. Redhead, E. V. Kornelson and J. P. Hobson: Can. J. Phys., 40 (1962) 1814.

2) L. L. Blackmer and H. E. Farnsworth: Phys. Rev., 77 (1950) 826; C. F. Ying and H. E. Farnsworth: ibid., 85 (1952) 485.

3) H. E. Farnsworth and H. H. Madden: J. appl. Phys., 32 (1961) 1933.

4) R. Smoluchowski: Phys. Rev., 60 (1941) 661.

5) P. A. Redhead: Vacuum, 12 (1962) 203.

6) R. O. Rantanen, A. L. Moen and E. E. Donaldson: J. Vac. Sci. Tech., 7 (1970) 18.

7) J. F. Truhler, E. E. Donaldson and D. E. Horne: J. appl. Phys., 41 (1970) 2139. 